\title{
Imagining the carbon neutral city: the (post)politics of time and space
}

\author{
Anneleen Kenis and Matthias Lievens
}

This is the accepted version of an article published in Environment and Planning A: Economy and space. Check the following website for the published version:

https://journals.sagepub.com/doi/abs/10.1177/0308518X16680617

To cite this article: Kenis, A., Lievens, M. (2017). Imagining the carbon neutral city: the (post)politics of time and space. Environment and Planning A, 49 (8), 1762-1778, DOI:

$10.1177 / 0308518 \times 16680617$.

\begin{abstract}
Putting climate neutrality on the urban agenda inevitably requires a re-imagination and delineation of the boundaries of the city, both at the geographical level, with regard to its inscription in history and concerning the social groups it is composed of. Such an exercise of (re-)imagination or representation is a profoundly political act. It is on the level of this symbolic representation that the (de)politicised nature of sustainability projects must be assessed.

LKN2030, a project which aims to make the city of Leuven (Belgium) carbon neutral by 2030, is a case in point. The way it delineates its spatial boundaries, inscribes itself in time and conceives of the main actors representing the city generates profound forms of depoliticisation. Our contention is that these can explain some of the obstacles the project currently faces, whereas it initially triggered a lot of enthusiasm. Though mechanisms of in- and exclusion and agenda-setting inevitably take place in every sustainability project, in LKN2030 these choices tend to be neutralised behind a technical, managerial and scientific discourse. As a result, the project risks to translate potentially interesting dynamics into a consensual project for urban renewal and city marketing, whereby sustainability goals are reframed into marketing objectives and economic opportunities. Drawing on post-foundational political theory, this paper assesses this evolution, but also explores the potential of forms of repoliticisation that are emerging in its wake.
\end{abstract}

'Rather than seeing the climate challenge only as a burden, Leuven has all interest in considering it as a unique opportunity.'

Project Proposal Leuven Climate Neutral 


\section{Introduction}

Overlooking the landscape of contemporary climate politics, three tendencies can be observed. First, international climate negotiations have led to successive failures, symbolised by wafer-thin agreements, lack of substantial commitments and raising global $\mathrm{CO}_{2}$ emissions. Even the 2015 Paris agreement, which represents a substantial step in international climate action, remains largely insufficient to ward off runaway climate change. Second, we see an ongoing attempt to reframe the climate challenge in more market-oriented terms, as a chance to reform and recover the market economy, a tendency which is especially epitomised by the emerging green economy discourse (Mueller and Bullard, 2011; Mueller and Passadakis, 2010; Kenis and Lievens, 2015, 2016). Third, there is a tenacious tendency to represent the climate crisis in consensual, managerial and technocratic, or in other words, depoliticised terms (Bettini, 2013; Goeminne, 2010; MacGregor, 2014; Machin, 2013; Maeseele, 2015; Pepermans and Maeseele 2014; Kenis, 2016; Kenis and Lievens, 2014, 2015; Kenis and Matthijs, 2014a; Swyngedouw, 2007; 2010; 2013). The emergence of a myriad of city-level initiatives to tackle climate change is symptomatic of all these trends. The decreasing hope to realise far-going climate action on an international level has strengthened the idea that initiatives should be taken on lower scales, such as the city. This is also supposed to be an ideal level to experiment with green economy scenarios, new forms of governance and multistakeholder participation (LSE Cities, 2013; UNEP, 2011; UNICE, 2011). The idea is that the transition towards a more sustainable society could be realised through the 'viral' spread of city-level initiatives set up by 'enlightened' city councils, often in collaboration with entrepreneurs and other 'frontrunners', who would not wait for decisions from above to take action (Jones and De Meyere, 2009).

A typical example is the case of Leuven Klimaatneutraal 2030 (LKN2030), 'Leuven Carbon Neutral 2030'. Leuven is a small city of about 100.000 inhabitants, situated in the Dutch-speaking part of Belgium on a distance of about $20 \mathrm{~km}$ from Brussels. It has few industries, but houses one of the largest universities in the country (KU Leuven), which has more than 11.000 staff members and 40.000 students. In 2011, the city not only signed the EU Covenant of Mayors, but also took the initiative to go a step further and set up a transition pathway towards carbon neutrality in 2030 . The aim of the project is to realise 'net zero $\mathrm{CO}_{2}$ emissions by the way we live, dwell, work, transport 
ourselves' (LKN2030, 2016). While the project initially triggered a lot of enthusiasm, it faces major obstacles today. While these obstacles are complex and diverse, this article particularly focuses on the key question of how LKN2030 has dealt - or failed to deal with the inevitably political dimension of such a profound process of change. The aim of this paper is to provide a theoretically grounded analysis of the ways in which the specific imagination of the carbon neutral city, particularly in terms of its spatial and temporal dimensions and its social composition, can lead to processes of depoliticisation. Key questions in this context are what kind of image a city gives of itself, how it draws its boundaries, views the composition of its population or imagines its geographical and historical inscription, and to what extent these representations can be considered as (de)politicised. At the same time, as we will show, the symbolic shift resulting from the emerging discourse on urban climate neutrality also generates a potential for forms of repoliticisation. The argument of the paper proceeds as follows. We first provide a short sketch of the project, its main developments and its key features. Subsequently, we discuss the debate about the concept of the 'political', mainly drawing on post-foundational political theory (Marchart, 2007). We argue that (de)politicisation in a project for climate neutrality relates to how the city is imagined, represented or given meaning. In the fourth section, this argument will be brought to bear on the spatial, temporal and social imagination underpinning the project of LKN 2030. In order to illustrate these points, we will shortly elaborate three cases of forms of opposition or agonism which developed within the framework of LKN2030: the case of a planned underground parking plot, the case of the 'Parkveld' movement advocating sustainable urban agriculture, and the case of a real estate project developer failing to live up expectations. We argue that despite the depoliticised nature of its representation of space, time and its composition, the symbolic shift which LKN2030 produces also creates the framework for new potential forms of repoliticisation. The symbolic inscription of the long-term goal of climate neutrality provides critical civil society actors with the discursive tools to attempt to repoliticise the processes at stake. As we will conclude, the empty signifier 'climate neutrality' does not only open the door for its appropriation by a green economy discourse or for city marketing, but can also provide the frame for new forms of opposition and repoliticisation. 


\section{LKN2030: the emergence of a project}

The idea to make Leuven carbon neutral by 2030 was launched in 2011 by a number of scholars from the University of Leuven, who quickly found a willing ear with the responsible alderman. Inspired by literature on transition management (Kemp et al., 2007; Loorbach, 2007; Loorbach and Rotmans, 2006; Rotmans, 2003), the project was framed as a multi-actor engagement in which the city's key social actors (policy-makers, business sectors, academic institutions, civil society actors and utility companies) would be involved. Through dialogue and in consensus, a number of transition paths would be set up which should enable Leuven to become carbon neutral by 2030 (Jones et al., 2012). As regards funding, the project would rely on 'common efforts by the city, the university and the business world' (Jones et al., 2012).

A combination of operational and strategic transition management was supposed to integrate a bottom-up and a top-down approach (Jones et al., 2012; Vandevyvere et al., 2013). Via six thematic cells (energy, built environment, mobility, agriculture and nature, consumption, transition and participation) actors and experts 'from the bottom up' were invited to bring in their expertise and commitment. A number of climate parliaments, through which a few hundred people voluntarily participated in the project, allowed citizens to express their points of view and bring in relevant ideas or expertise. At the same time, a transition arena, named the G20, was launched, embodying a 'top-down approach' in which 'visionary and important key actors' would take the fore (Jones et al., 2012; see also Jones and De Meyere, 2009; Loorbach, 2007; Loorbach and Rotmans, 2006; Rotmans and Loorbach, 2009). Including 20 'visionary system thinkers' (from the city council, businesses, civil society and the university), its aim was to reflect on the high-level strategic choices the city should make. The combination of the transition arena with the thematic cells and climate parliaments was not only aimed at building the necessary knowledge base and generating real impact, but was also supposed to facilitate what the initiative called a 'citywide project' and a 'unique participation process' (LKN2030, 2012a). Importantly, these structures only operated during the launching period of the project. Since its official start in 2013, a nonprofit association, chaired by the responsible alderman and consisting of 15 actors (from the city government, business sectors, knowledge institutions, civil society and (semi-)public utilities), has become the key agent in the transition process. In analogy to the earlier thematic cells, a few dozens of 'yards', working on issues such as collaborative 
renovation of houses, car sharing or the local production of renewable energy, complement the main steering body in order to acquire a wider outreach and participation.

While the projection of Leuven as the first climate neutral city of Belgium initially triggered quite some enthusiasm, and a lot of actors became involved in a short lapse of time, gradually the project lost some of its momentum, as a number of critiques, questions and doubts started to emerge. In this article, we will discuss a number of these shortages, particularly in relation to the issue of depoliticisation, a concept which has become the linchpin of a novel form of ideology critique.

\section{Post-politics as representation}

For as long as the word 'politics' exists, it has been associated with the city, the polis. Cities have provided the setting for defining the very concept of politics, including the meaning and scope of democracy, citizenship, in- and exclusion etcetera (Arendt, 1998; Balibar, 1998). However, critical scholars have increasingly drawn attention to processes through which cities have recently become the sites of technocratic forms of policymaking, governance arrangements and city marketing, all of which have been referred to as 'post-political' (Harvey, 2012; Heynen et al., 2006; Swyngedouw, 2005, 2009; Swyngedouw and Kaika, 2014). What is of the essence of politics, it is argued, including the struggle for power between actors defending alternative visions on city life, is increasingly misrecognised or sidelined in favour of more consensual, technocratic and market-oriented approaches.

At the same time, this introduction of the notions of post-politics and depoliticisation into (urban) sustainability studies (Swyngedouw, 2009; Swyngedouw and Kaika, 2014) sparked some controversy, as other scholars have criticised these concepts for misrecognising the democratic processes and forms of pluralism that actually exist (Chatterton et al., 2013; Featherstone, 2013; Larner, 2014; McCarthy, 2013; North, 2010; Urry, 2011). It is important, therefore, to clarify some conceptual issues in relation to the notion of 'post-politics' in order to avoid it becomes an empty slogan which can be applied too easily on almost everything.

The political is a complex concept, full of paradoxes. This is especially because stating that something is political is not just a description of fact, but has a performative thrust: to call something political is itself a political act, just as calling something non- 
political is. As Carl Schmitt famously stated, 'any decision about whether something is unpolitical is always a political decision' (Schmitt, 1988). In other words, statements that something ought to be beyond politics often have a political significance. In this sense, Anthony Giddens' (2009) argument that '(c)limate change should be lifted out of a rightleft context, where it has no place' could be read as a highly political statement with important implications for the right-left opposition. Another such paradox relates to the well-known statement that 'everything is political' (Bensaïd, 1997). Would it not be the case that if everything is political, nothing is (Marchart, 2007; Rancière, 1999)?

The crux of the matter is that we cannot state that certain social relations, acts or things are intrinsically or essentially political, while others are not. Fundamentally, the political is about how things are discursively represented, given meaning, imagined (Kenis and Lievens, 2014, 2015; Lievens, 2012, 2015). Following Lefort (1986, 1988), we could even argue that 'the political' is the order of symbols and significations, or 'the symbolic order' through which society is given meaning. Representation is key, in other words: it is through the representations that accompany practices of governing, struggling or deciding that a meaning is given to what living together in a society means and entails. Or, to put it differently, an act is political precisely because it has a specific meaning, and embodies a specific vision on how (e.g. urban) society should be organised, and according to which principles. The key question then becomes whether discourses through which the act of governing is signified acknowledge their political nature and purport.

In this perspective, it is our contention that notions such as 'the political' and 'depoliticisation' should be considered as the linchpins of a novel form of ideology critique (Lievens 2012; Kenis and Lievens, 2015). While older traditions of ideology critique aimed at uncovering how ideology distorts or conceals social relations, expresses hidden social or economic interests, or is the expression of hegemonic projects (e.g. Gramsci, 1998; Parekh, 1982), this novel form of ideology critique adopts another perspective: it does not ask what is 'behind' the discourse, but whether it acknowledges within itself that it has a political, and therefore contingent and contestable nature.

In this article, we use the terms post-politics and depoliticisation interchangeably. We actually prefer the term 'depoliticisation', as the notion of 'postpolitics' problematically suggests a historical succession has taken place whereby we 
were once political and now no longer. Depoliticisation also allows us better to single out particular discourses for critique, while post-politics often refers to a whole era, a period, or a 'condition'. One of the reasons why we still use the term post-politics as well, is that this is the term which was used by a number of post-foundational authors which inspire our analysis (Mouffe, 2006; Žižek, 2000), while depoliticisation is an older term, which also has been given other meanings than the one intended here (e.g. Castoriadis, 2010).

Simply put, in the context of this article those discourses are analysed as depoliticised that misrecognise their character as discourses, as social constructions which are contingent, but nevertheless (co-)constitutive of our current form of society, and which can generate exclusions or render us blind to the necessity or possibility to act or commit ourselves. Different authors have approached this issue in slightly different terms, but the representational misrecognition of power, exclusion and contingency are red threads throughout the debate on post-politics and depoliticisation (Marchart, 2007; Mouffe, 1993, 2006, 2013; Rancière, 1999, 2001, 2005; Žižek, 2000).

In the context of this paper, a relevant question is what kind of representation does the discourse of LKN2030 give of the city? What imaginary of city life is behind it? How does it represent urban change, the actors involved and the processes they engage in? How does it imagine the spatio-temporal configuration within which transition ought to take place? An increasing amount of literature criticises multistakeholder, managerial and governance discourses precisely for the way in which they fail to acknowledge or provide a place for radical plurality, conflict and dissensus, the contestation of exclusions, and the power relations they are engaged in (Deneault, 2013; Mair, 2006; Offe, 2009; Kenis, Bono and Mathijs, 2016; Lievens, 2015; Swyngedouw, 2005). A key question guiding this paper is how sustainability projects such as LKN2030 are affected by such forms of depoliticisation and how this impacts upon the project's effectiveness and democratic potential.

Projects for carbon neutral cities exhibit a strange paradox in this regard. The transformations they intend to realise are quite substantial and even radical, while their discourse on partnerships, win-win situations and multistakeholder cooperation fails to adequately grasp the inevitable trade-offs and difficult decisions and choices that will have to be made. Moreover, even though creating an attractive 'Leitbild' (leading image) is key to the kind of transition process LKN2030 engages in (Loorbach, 2007), no real 
recognition is given to the fact that realising climate neutrality implies a fundamental, and politically significant transformation of social and political values and priorities. As we will argue, this will turn the process of making Leuven climate neutral into a politically charged process, but one which is not recognised as such.

Significantly, the project does have important symbolic effects, as a result of which the novel imagination of the city, its spatial boundaries, its temporality and its composition can become starting points for processes of repoliticisation. Indeed, as Chantal Mouffe $(2002,2006)$ or Slavoj Žižek (2000) have argued, the political dimension cannot be simply wished away, but will always remain present underneath the surface, and therefore risks to return in different guises. Inevitably, 'the disappearance of the political in a postpolitical arrangement leaves all manner of traces that allow for the resurfacing of the properly political' (Swyngedouw, 2009). In our discussion of LKN2030, we will therefore also discuss critical points of (potential) repoliticisation.

\section{Imagining the climate neutral city}

Projecting a future climate neutral city requires imagining the city, its boundaries and its development in particular ways. It entails an act through which the city is carved out as a specific, bounded place distinguished from its 'environment', embedded in a specific temporality or historicity, and composed of specific groups of people. In other words, imagining the city implies answering questions about 'where', 'when' and 'who': in which geography and history is the city inscribed, and who is part of it? In order to assess LKN2030 from the point of view of 'the political', this section will analyse how Leuven is socially constructed as the object of climate neutralisation through specific symbolic or discursive strategies.

\subsection{Where is the city? The impossible place of climate neutrality}

First and foremost, the project of the carbon neutral city entails a specific spatial delineation of the city, a process whereby contestable choices and decisions are made. What will be included in the effort to make Leuven climate neutral, and what will not? Evidently, the city is embedded in a broader, complex metabolism composed of flows of 
energy, matter, and waste (Heynen et al., 2006). Which flows or aspects of them will be considered as part of the 'city', and which will be abstracted from? Projecting a climate neutral city entails the inevitable but impossible attempt to carve out a space within this broader metabolism. On the one hand, such a reduction of complexity is the condition of possibility for the project, as it allows its protagonists to identify strategies and priorities for climate neutralisation within a clearly circumscribed location. On the other hand, it is an impossible task: how to meaningfully disentangle the broader metabolism and claim that climate neutrality is reachable while abstracting from certain dimensions of this metabolism? Leaving out certain flows from the broader metabolism is a relatively contingent and arbitrary act, making the concept of carbon neutrality vulnerable. Drawing inspiration from Derrida's notion of undecidability (Derrida, 1992, 1994; Marchart, 2007), we can argue that it is precisely in this aporia between the necessity to make a decision on which part of a city's metabolism to include, and the impossibility to make a final and grounded decision on this issue, that a space of political contestability resides.

How did this process of constructing the boundaries of the city within a broader metabolism proceed in the case of LKN2030? In order to set out a transition path, the main sources of emissions on the territory of Leuven were first mapped through a baseline measurement (LKN2030, 2012b; Vanderheyden et al., 2012). Three types of emissions were distinguished: the direct emissions which result from activities taking place in Leuven, such as heating buildings, transport or industrial processes (scope 1); indirect emissions generated elsewhere for the production of energy consumed in Leuven (scope 2); and indirect emissions generated elsewhere through the production of goods and services consumed by inhabitants of Leuven, or which result from inhabitants' activities taking place outside of Leuven, such as commuting or travelling abroad (scope 3).

Significantly, the plan to make Leuven carbon neutral only concerns scope 1 and 2 emissions, which in 2010 would have constituted a total of 808.000 ton $\mathrm{CO}_{2} \mathrm{eq}$ for the whole city. The project outline justifies this decision by stating that calculating scope 3 emissions is difficult and that the project's capacity to control these emissions is limited. Yet, this decision has important political implications. From a metabolic perspective, one cannot possibly understand the life of the city without including a number of activities taking place far beyond its institutional boundaries. As Swyngedouw and Kaika (2014) 
argue, the socio-metabolic logics of the urban cannot be constricted to the institutional boundaries of the city: 'a much greater number of people that often do not live in places defined as "cities" are directly or indirectly involved in ensuring the continuation of the global urbanization process'. Indeed, city-level carbon neutrality projects most often partake in spatially uneven transition processes, combining the continued consumption of emission-intensive goods produced far away with eco-technologies nearby.

Referring to $19^{\text {th }}$ century textile production, Jason Moore (2015) states that 'for every Manchester' there is 'a Mississippi Delta', thus pointing out the blind spot of an exclusive focus by political economists on what happens within the factory. We can paraphrase this by stating there is no Leuven without resource extraction, agricultural activities, industries and transportation networks reaching out to the other side of the planet. That the contribution of these activities on the level of greenhouses gases is significant is evidenced by the fact that scope 3 emissions are estimated to be at least as high as scope 1 and 2 emissions combined. Importantly, the impact of scope 3 emissions need not only be searched for at the other side of the globe, but also relates to nearby (agricultural) practices. Sustainable urban agriculture initiatives exactly try to bring (food) production close to home again (Tornaghi, 2014). An important side effect of the decision to exclude scope 3 emissions from the purview of LKN 2030 is that the importance of such initiatives is thus downplayed.

On the basis of this restrictive definition of the spatial boundaries of the city, 'buildings' and 'mobility' became priority targets as they turned out to represent the largest share of emissions, respectively $60 \%$ and $25 \%$. In so far as agricultural activities already have a place on the territory of Leuven, they are included in scope 1 . But beyond that there is in LKN2030 no incentive to make food production more sustainable by localizing it (e.g. promoting 'food not lawns' initiatives, turning city parks into edible parks, advancing urban bee keeping, or freeing place into the city for urban food gardens to give just a few examples of practices which have been central to other transition initiatives (Mason and Whitehead, 2012; Neal, 2013; Kenis and Mathijs, 2014b; Tornaghi and Van Dijck, 2015)). To put it metaphorically, on the level of scope 1 and 2 emissions, it does not matter if the trees in the park are oaks or pear trees. But it does matter for climate neutrality in the broader sense of the word.

This is not only a theoretical argument. Action groups and NGOs working on sustainable agriculture blame LKN2030 for misrecognizing or rendering invisible their 
topics, as a result of a particular framing of climate neutrality. An important case in point is the activist group 'Parkveld blijft', which struggles for safeguarding a green zone just outside the city centre which the municipal authorities have targeted for new land development, including offices, apartment building and houses. 'How will you realize climate neutrality without Parkveld?', the activists critically asked during a public debate on the topic. A number of them have squatted the terrain, and turned it into popular gardens as the linchpin of their campaign for the maintenance of the green zone and for the promotion of sustainable urban agriculture. Significantly, the reference to Leuven Climate Neutral 2030 operated as a key discursive tactic for the movement, whereby it also implicitly questioned the reduction of relevant emissions to scope 1 and 2 . Interestingly, the website of LKN 2030 announced a number of activities of the group, which shows both that diverging voices are present in LKN2030 and that these divergences are tolerated to a certain extent.

To be clear, our argument is not that buildings or mobility are no laudable policy priorities, nor that LKN2030 constructed the boundaries of the city in a false way, or that it ought to have included at least certain scope 3 emissions. Any strategy for a sustainability transition will have to carve out a space within which it aims to realize specific changes. Precisely because the urban 'stretches from the immediate environment to the remotest corners of the globe' (Heynen et al., 2006; Swyngedouw and Kaika, 2014), one could argue that it is inherent to carbon neutrality projects to disregard certain types of emissions, and to draw the boundaries in a way that is always somewhat arbitrary.

Our point is that this process of boundary construction is based on decisions that remain contingent and contestable, and that there is a problem if they are rendered invisible by a scientific or technical discourse (referring for instance to the so-called 'immeasurability' of scope 3 emissions). The boundaries by which a carbon neutral city is circumscribed are the object of political decisions that should remain contestable and that is what the emerging movement for sustainable urban agriculture in Leuven is doing to a certain extent. At the same time, the observation of the constructed nature of urban boundaries inevitably undermines the full meaning of 'climate neutrality' in the material sense of the term. It shows that this latter signifier remains relatively empty (Laclau, 1996), and that it is therefore unavoidably the object of a hegemonic process through which the spatial configuration of the city is constructed. As we will argue in what 
follows, not only the baseline measurement of carbon emissions in a city and the setting of priority targets, but also the specific timing of the project and the choice to mobilise particular social groups partake in this process of construction.

\subsection{Whither the city? Climate neutrality and the politics of time}

The attempt to make Leuven carbon neutral not only presupposes a spatial delineation of the city, but also entails a particular understanding of its temporality and historicity. In the philosophy of transition management, a process of change starts with the elaboration of an enthusing Leitbild, an ideal image of a sustainable future, rooted in contemporary developments and realities of the city. Although the scientific report of LKN2030 calls for a participatory process for the construction of such a Leitbild, no systematic attempt has been made so far to develop such an image, although Leitbilder have been developed with regard to specific issues and visioning is generally one of the key ingredients of LKN2030's approach. For example, the scientific report ordered by LKN2030 advocates as a Leitbild the '33/33/33' model for mobility, attributing an equal share to cars, bicycles and public transport (Jones et al., 2012).

To a certain extent, this development of visions or Leitbilder amounts to an exercise in projecting a 'concrete utopia', to recycle a term Ernst Bloch (1986) developed in an entirely different context. In such imaginations, whether of a 'Leitbild' or a 'concrete utopia', the future is the dominant category. This contrasts with politicised conceptions where not the future but the 'now moment' is the dominant category, as is the case with Walter Benjamin's understanding of time. In this context, Daniel Bensaïd points to the loss of political intensity in the now moment which might result from an attitude of patience inspired by a future utopian image. As he states, 'there are delays which makes one miss an appointment. There are missed appointments which are irreparable' (Bensaïd, 1995). As he argues, thinking politically requires not merely the projection of a better future, but the recognition in each now moment of a possibility to act. Looking forward to a utopian future should not be incompatible with a keen sense of the present, but in actual practice, this is often the result, Bensaïd suggests. Politicising time is thus not just about projecting a better future, but about grasping the possibilities and stakes of the present. 
Although these quite sophisticated theoretical arguments emerged in another context, they do shed light on forms of depoliticisation in LKN2030's relation to time. 2030 appeared far away on the moment the responsible alderman signed a declaration of intention in 2011. Decisive choices did not need to be made yet, so it seemed, or they can be patiently scheduled over a number of years. Everything is still possible ... in the future. At the same time, Leuven can now already present itself as a green city, merely on the basis of its intention to become climate neutral at a later moment in time. In this way, the city government appears to play the game of time intelligently, already profiling itself as 'green' on the basis of future projects which might perhaps never be fully realised. However, faced with the reality of climate change, this game of time may turn not have been so intelligent after all. Is a lack of action here and now, hidden behind a seductive imagine of a sustainable utopia, still reparable in the future?

In his reflections on political temporality, Walter Benjamin was mainly thinking about world-historical events such as the struggle against fascism, which required action in the 'now moment' to avert the coming catastrophe, and which could not be postponed until tomorrow. Understanding this requires a 'full' conception of time. This means that each moment carries its own possibilities for action and initiative, and that these possibilities can be lost when they are not seized at the 'right' moment. Many political theorists have stressed this dimension of 'full' time. Through his notion of 'fortune' Niccolò Machiavelli (1998) emphasised the importance of the right moment or 'kairos' to take decisive political action. Carl Schmitt (1988) stressed the need to decide at the moment of crisis (see also Lievens, forthcoming). Walter Benjamin (2007) especially denounced the notion of empty time underpinning the thought of social democrats who failed to understand the extent of the fascist danger in Germany in the 1930s and misrecognised that one could not postpone the struggle until tomorrow or schedule the struggle at wish (see also Bensaïd, 1990; Löwy, 2001). The time of the political is the time of events, which can occur unexpectedly, but which need to be seized upon, because when they are missed, the opportunity or possibility they provided will never recur. Such a full, political conception of time contrasts with an 'empty' understanding of time, the time of the calendar, where each moment equals all others.

If LKN2030 did not seize the momentum and the enthusiasm that the project triggered initially one can wonder whether a crucial moment was not missed. Is the same still possible in the future? Will citizens still be willing to engage in the same 
committed way and make the project into one of their own? Will companies still believe that something of importance is at stake and that they have something to win? Will a plurality of organisations still be interested in linking their engagements with LKN2030?

Such questions can not only be asked with regard to the social and political dynamics of collective commitment. Something similar is at play with regard to the built environment, as infrastructural decisions can generate lock-ins for years to come. A case in point is the decision by the city council majority to build an underground car park with a capacity of 600 cars in the centre of the city. The scientific report drafted before the launch of LKN2030 argues that 5000 extra parking places have to be built outside the city centre, and 3000 have to be suspended in the area within the ring road (Vandevyvere et al., 2013). The decision to build extra parking places within the city centre is therefore viewed as fundamentally at odds with the intentions of LKN2030 as it will attract more cars to the city. Furthermore, critics, including within LKN2030, argue that it radically impedes more fundamental changes in the future as it will take decennia before the new parking's costs are amortised. To quote one of the pioneers of LKN: 'Building a new car park in the centre of Leuven is not compatible with the needed climate neutral transition path to an ultimately low-traffic city centre in 2030. Those who claim it is, demonstrate an outspoken form of cognitive dissonance'. Responding to this critique, the current chair of LKN2030 resorted to a typical techno-utopian argument. In a debate in November 2013 he stated he believed that by that time all cars would be electric so they would not be an issue for climate neutrality anymore. Adding another depoliticising discursive move, he urged the audience to be 'optimistic' and not to be overly critical: solutions will be found, so he argued.

From the point of view of the concept of the political, what is of interest in this case is that a particular form of depoliticisation is key to understanding the deeper roots of this conflict. This is not merely a conflict between different agendas, between promise and practice, between high ambitions and a limited political will. It is rooted in a deeper chasm between an empty, depoliticised conception and a full, political conception of time. On the one hand, there is the idea that climate neutrality is to be built step by step, and what cannot be done today, will be solved tomorrow. Technological improvements will soon deliver affordable electric cars, downplaying the very threat extra car parks pose for the goals of LKN2030. In the future more will be possible than today anyway. 
This bet on the future relies on an empty and non-political conception of time, projecting the spontaneous arrival of technical solutions through a gradual progress.

Underpinning the opposition movement's discourse is a full conception of time: this is a missed opportunity, and a missed opportunity does not return, there is no second chance. In the words of a local politician: 'You don't build an underground parking for five or ten year. If you build it, it is there for at least 60 or 70 year' (Dessers, forthcoming). On the website of the action committee against the parking, which denounces the contrast between high climate ambitions and the construction of new car infrastructure, it is stated that 'the car will not disappear from the city, it only becomes less visible' (as the car is put under the ground) (DeBruulBrult, 2016). The 2030 goal is unreachable in this way, it is argued, and will have to be adjusted. To put it in our own conceptual vocabulary, if important 'now moments' are missed, the empty time of transition management becomes untenable anyhow. It is significant that the year '2030' is increasingly dropped from the name of the initiative.

The time of climate change is not empty and homogeneous, but 'full' and marked by critical thresholds and turning points. Similarly, the time for climate action is 'now', meaning that each and every political event or moment can be seized to make steps towards another socio-ecological future. A reliance on an empty conception of time means many 'now moments' can be missed.

\subsection{Who is the city? Participation or democracy?}

Originally four, and later five sectors were identified as key players that needed to get involved in order to make the city climate neutral: business, civil society, municipal authorities, knowledge institutions, and later also public utilities. Individuals selected from each category were first included in the project's transition arena, and later in the board. Although they were all considered key to the success of the project, particular effort was done to get businesses involved. As the project depends for a big part on the latters' 'green' investments, their participation was seen as crucial. In order to persuade them, the possibility of green branding was strongly emphasised. For instance, in the promotion booklet it was stated that 'all relevant stakeholders' would be 'put extensively in the spotlights' (Jones et al., 2012), allowing them to benefit from their participation as it would give them a share of publicity. Moreover, the development of 
cost-neutral scenarios and the pursuit of win-win solutions were supposed to trigger business interest. After shortly introducing the background of LKN2030, the project proposal includes a long section entitled 'green city branding', which adopts a typical green economy discourse presenting climate change as an economic and technological opportunity. In the press conference launching LKN2030, reference was made to Copenhagen as an example of how a green city project can become 'a catalyst for "Green Growth"'. The discourse is typically woven around nodal points such as 'economic opportunities', 'Leuven as a pioneering example', and 'city marketing and image', around which extensive communication campaigns are built. Following a transition management approach, the hope is that once business actors are part of the conversation, they will develop a more intrinsic motivation to engage in a sustainability transition (Loorbach, 2007). Through a process of dialogue and consensus-seeking, initially instrumental or strategic motivations would thus be transcended or transformed. A crucial question is of course whether this also materialises in practice (Kenis, Bono and Mathijs, 2016).

A transition arena is based on the idea that through in-depth conversations between so-called 'important' actors (Jones and De Meyere, 2009) who are considered 'frontrunners' in their respective fields (Rotmans and Loorbach, 2009) consensus can be found on the need of a sustainability transition. Crucially, participants are asked to transcend power games and personal interests in order to arrive at a rational, genuine and fruitful kind of dialogue. Transition management thus follows a typical deliberative approach to decision-making (Dryzek, 2010). However, scholars such as Mouffe (2000) have convincingly criticised the limits of this deliberative approach, arguing that power cannot so easily be pushed aside, and interests do not disappear by 'ignoring' them (see also Machin, 2013). LKN2030 seems to be a case in point as it soon turned out that a gap was lurking between several actors' commitment and their actual practices. Most notable is the case of a real estate project developer who got the opportunity to set up the largest sustainable housing project in an urban centre in Flanders, including 1200 residential units on a terrain of 11 hectares, within the framework of LKN2030. However, despite promises to integrate and preserve old buildings that are part of the cultural patrimony of the city, after just a few years the officially protected buildings are left unattended and in a dilapidated state, and will be bought and rescued by the municipality. The company sold off non-profitable parts (including a kindergarten and 
social housing project), let inhabitants overpay for maintaining the new buildings, and as the symbolic drop in the bucket, sprayed weed killers on adjacent lawns. Inhabitants sent a letter to the LKN2030 secretariat announcing their disengagement from the project as long as the company remains part of its executive committee.

This brings us to the question who is included in the transition arena, or more recently the board of LKN2030, and who is not, and why that is the case. According to post-foundational political theory (Marchart, 2007), who is part of leading institutions in society, and how these present themselves to citizens is of key importance. For Lefort (1988), for example, representatives hold a mirror to society, as they display the latter's composition, its key principles and values, making these not only visible but also contestable (see also Weymans, 2005). From that perspective, the question becomes what kind of city we have when actors like the involved project developer are key members of what constitutes LKN2030's decisive organ, or what image the city gives of itself when a small set of 'system thinkers' can chart a process of change that is supposed to have a determinative effect on its future as a whole? Whether transition managers acknowledge this or not, the participants in the transition arena (or in other leading organs such as the board) are representatives in a certain way, and it is of crucial importance to recognise this.

Within the transition management approach participants are supposed to participate on their 'personal account', thus not representing anyone apart from themselves (Van der Brugge and Rotmans, 2007). The hope is that this will facilitate the process to arrive at a common problem definition and goal. Within the framework of a deliberative theory of democracy this is defendable as it is not so important who is represented, the key question being whether all relevant arguments can be heard (Geenens, 2007). However, from a democratic point of view, such an approach can have problematic implications (Kenis, Bono and Mathijs, 2016). As Flor Avelino (2009) states, to opt for this particular group of people can be very exclusionary. Furthermore, in many transition initiatives, the selection of specific actors who are considered 'important' or 'frontrunners' is not made in a very transparent way (Kenis, Bono and Mathijs, 2016; see also Hendriks, 2009). This is not different in LKN2030. The basic mechanism is one of cooptation, whereby the initiators select and include specific people they know or deem interesting or influential. While the choice to work with a transition arena is often inspired by an attempt to facilitate new forms of participation, the dynamic it engenders 
can impede broader forms of participation by citizens or civil society groups that are not involved. Moving beyond a typical transition management approach, LKN2030 tried to compensate for this by complementing its transition arena with six thematic cells and a limited number of climate parliaments which were meant to give a voice to a broader range of citizens. Yet, while these parliaments were generally considered as successful and interesting, attracting a few hundreds of voluntary participants, they did not really counterweigh the democratic deficit as they functioned primarily as mechanisms of consultation. Whereas citizens got a voice, they did not get a vote.

Importantly, participation cannot simply be equated with democracy. From the point of view of post-foundational political theory, contestability and the capacity of a society to recognise and fairly deal with its dividedness is much more important, and participation is actually seen as the paradoxical result of this (Lefort, 1988; Mouffe, 2006; Rancière, 1999). It is by staging division and making visible that something profound is at stake, that citizens are challenged to take sides and participate in the conversation. Making dividedness visible is, for instance, one of the key symbolic contributions of the majority/opposition split in parliamentary democracy, which shows to society that it is divided but that this division or disagreement is legitimate (Lefort, 1988; Lievens, 2015). This is not meant to idealise the classic forms of parliamentary democracy, quite the contrary, though it is important to see what is lost by opting for new forms of governance and participation. The crucial question, again, is how the city is imagined or represented. Projects of city-wide multistakeholder governance, like LKN2030, give a very specific and depoliticised representation or image of urban society, based on all-round cooperation and inclusiveness, while they are actually led by a very particular set of actors and inevitably make politically significant and potentially divisive decisions.

\section{Conclusion: between city marketing and repoliticisation}

As is often the case with eco-city projects, the very limited progress towards carbon neutrality stands in sharp contrast with the high ambitions formulated originally (Cook and Swyngedouw, 2012; Swyngedouw and Kaika, 2014). Materially, not so much has changed, but in the case of Leuven, important symbolic changes have taken place: 
climate neutrality has become key to the city's self-image, as a result of which critical local issues, discussions and agendas are (re)framed. Importantly, it is also on this symbolic, discursive or representational level that processes of (de)politicisation have to be judged.

Crucially, symbols are of key importance for launching or inhibiting effective dynamics of change. At the same time, they can also conceal their political stakes. Through its appropriation for divergent policy agendas, 'climate neutrality' has started to function as a 'tendentially empty signifier' (Laclau, 1996; 2001), fitting within diverging hegemonic projects, including both oppositional movements for radical sustainable alternatives and city marketing initiatives. The focus on city marketing is politically significant, as the general interest of the city is thus framed in terms of a logic of marketing, economic opportunities and competition. The result is not only that the political stake of the project is submerged in an economic and managerial discourse. What was originally intended as a 'means' (a green economy or city marketing discourse in order to get business actors on board) soon became an 'end' in itself.

At the same time, the signifier of 'climate neutrality' can also be appropriated and resymbolised by other actors, and can in this way become the starting point for processes of repoliticisation. Indeed, precisely because the term is tendentially emptied, it can also provide symbolic support for the democratic expression of disagreement by movements who advocate radical sustainable alternatives. The opposition to the construction of a new car parking, pitting the city council majority against some (other) protagonists of LKN2030, the movement for safeguarding agricultural land in Leuven, and the call to exclude the real estate project developer referred to above from the LKN2030 board are telling illustrations of how the symbolic reframing of the city has also provided opposition movements with new discursive weapons. In this sense, the political' returns, manifesting itself through a number of tensions and potential fault lines that have developed during the last years.

These examples also show that a project such as LKN2030 can never be as homogenous as it might appear on the basis of its official documents. A myriad of people, initiatives, opinions and strategies are involved, which are not always compatible. Importantly, this should not be seen as a problem. In a paradoxical way, conflict and opposition can raise the stakes of a policy project, as it can help mobilise the citizenry and enhance popular participation around it (Balibar, 1992, 1998, 2003; 
Mouffe, 2000; Rancière, 1999). Strong and visible disagreements on key notions such as climate neutrality, on what it should include and how it should be put into practice, can challenge previously uninvolved actors to take a stance, speak out and broaden the debate. In other words, conflict and contestation (or to put it differently: politicisation) can enhance democratic participation and involvement, because they make clear that something important is at stake. If the discussion takes place only within a consensual atmosphere, confined within the boundaries of a well-defined transition arena, it can never have such a dynamising and mobilising effect.

In a paradoxical way, one of the merits of LKN2030 is therefore that it has provided new starting points for debate and contestation and thus for processes of politicisation, even though its own discourse remains strongly post-political. Whichever social or environmental movement that emerges in the future will be able to refer to the cleavage between the ambitious objectives and the actual practices of the project. Social and ecological protest can gain legitimacy precisely because it can turn the city's own Leitbild and objectives against its actual policy practices. In an interesting way, even post-political projects can thus generate symbols that can be turned into starting points for political action. 


\section{References}

Arendt H (1998) The Human Condition. Chicago: University of Chicago Press, Chicago. Avelino $\mathrm{F}$ (2009) Empowerment and the challenge of applying transition management to ongoing projects. Policy Sciences 42: 369-390.

Balibar E (1992) Les Frontières de la Démocratie. Paris : La Découverte.

Balibar E (1998) Droit de Cité. La Tour d'Aigues : Editions de l'Aube.

Balibar E (2003) L'Europe, l'Amérique, la Guerre. Réflexions sur la Médiation

Européenne. Paris : La Découverte.

Benjamin W (2007) Theses on the Philosophy of History. In: Benjamin W Illuminations. New York: Schocken Books: 253-264

Bensaïd D (1990) Walter Benjamin. Sentinelle messianique. Paris : Plon.

Bensaïd D (1997) Le pari mélancolique. Métamorphoses de la politique, politiques des métamorphoses. Paris : Fayard.

Bettini G (2013) Climate Barbarians at the Gate? A critique of apocalyptic narratives on 'climate refugees' Geoforum 45: 63-72.

Bloch E (1986) The Principle of Hope. Cambridge: MIT Press.

Castoriadis C (2010) A Society Adrift. Interviews and Debates, 1974-1997. New York:

Fordham University Press.

Chatterton P, Featherstone D, Routledge P (2013) Articulating Climate Justice in Copenhagen: Antagonism, the Commons, and Solidarity Antipode 45(3): 602-620.

Cities LSE (2013) Going Green. How cities are leading the next economy. A global survey and case studies of cities building the green economy. Final report. London: London School of Economics and Political Science.

Cook I R, Swyngedouw E (2012) Cities, Social Cohesion and the Environment: Towards a Future Research Agenda Urban Studies 49(9): 1959-1979.

DeBruulBrult 2016 De klimaatneutrale stad: een oprechte ambitie of citymarketing? http://debruulbrult.weebly.com/ (Accessed 1 September 2016).

Deneault A (2013) Gouvernance. Le management totalitaire. Montréal : Lux.

Derrida J (1992) Force of Law: The 'Mystifical Foundation of Authority'. In: Cornell D, Rosenfeld M, Carlson D G (eds) Deconstruction and the Possibility of Justice. New York: Routledge.

Derrida J (1994) Politiques de l'Amitié. Paris : Galilée. 
Dessers D (forthcoming) Over Leuven Morgen. Pleidooi voor een andere stad. Leuven. Dryzek J (2010) Foundations and Frontiers of Deliberative Governance. Oxford: Oxford University Press.

Featherstone D (2013) The Contested Politics of Climate Change and the Crisis of Neoliberalism ACME. An International E-Journal for Critical Geographies 12(1): 44-64.

Giddens A (2009) The Politics of Climate Change. London: Polity.

Goeminne G (2010) Climate Policy is Dead, Long Live Climate Politics! Ethics, Place and Environment 13: 207-214.

Gramsci A (1998) Selections from the Prison Notebooks. London: Lawrence \& Wishart. Harvey D (2012) Rebel Cities. From the Right to the City to the Urban Revolution. London: Verso.

Hendriks C M (2009) Policy design without democracy? Making democratic sense of transition management. Policy Sciences 42: 341-368.

Heynen N, Kaika M, Swyngedouw E (2006) In the Nature of Cities. Urban political ecology and the politics of urban metabolism. London: Routledge.

Jones P T, De Meyere V (2009) Terra Reversa. De transitie naar rechtvaardige duurzaamheid. Antwerpen: EPO.

Jones P T, Vandevyvere H, Van Acke K (2012) Leuven Klimaatneutraal 2030.

Projectvoorstel Leuven Klimaatneutraal 2030. Leuven.

Kemp R, Loorbach D, Rotmans J (2007) Transition Management as a model for managing processes of co-evolution towards sustainable development. International Journal of Sustainable Development and World Ecology 14(1): 1-15.

Kenis A (2016) Ecological citizenship and democracy: Communitarian versus agonistic perspectives. Environmental Politics 25(6): 949-970.

Kenis A, Bono F and Mathijs E (2016) Unravelling the (post-)political in transition management: Interrogating pathways towards sustainable change. Journal of Environmental Policy \& Planning 18(5: The Politics of Transition): 568-584.

Kenis A and Lievens, M (2014) Searching for 'the political' in environmental politics. Environmental Politics 23(4): 531-548.

Kenis A and Lievens M (2015) The Limits of the Green Economy. From re-inventing capitalism to repoliticising the present. Routledge Studies in Environmental Policy, London: Routledge. 
Kenis A and Lievens M (2016) Greening the economy or economizing the green project? When environmental concerns are turned into a means to save the market. Review of Radical Political Economics 48(2): 217-234, art.nr.

10.1177/0486613415591803.

Kenis A and Mathijs E (2014a) Climate change and post-politics: Repoliticising the present by imagining the future? Geoforum 52: 148-156.

Kenis A and Mathijs E (2014b) (De)politicising the local: The case of the Transition Towns movement in Flanders (Belgium). Journal of Rural Studies 34: 172-183. Laclau E (1996) Emancipation(s). London: Verso.

Laclau E, Mouffe C (2001) Hegemony and Socialist Strategy : towards a Radical Democratic Politics. London: Verso.

Larner W (2014) The Limits of Post-Politics: Rethinking Radical Social Enterprise. In Wilson J, Swyngedouw E (eds) The Post-Political and Its Discontents. Spaces of Depoliticisation, Spectres of Radical Politics. Edinburgh: Edinburgh University Press, Edinburgh: 189-207.

Lefort C (1986) The Political Forms of Modern Society. Cambridge: MIT Press. Lefort C (1988) Democracy and Political Theory. Cambridge: Polity Press.

Lievens M (2015) From Government to Governance. A symbolic mutation and its repercussions for democracy. Political Studies 63(S1): 2-17.

Lievens M (2012) Ideology critique and the political. towards a schmittian perspective on ideology. Contemporary Political Theory 11(4): 381-396.

Lievens M (forthcoming) Carl Schmitt on History. In: J Meierhenrich and O Simons (eds) The Oxford Handbook on Carl Schmitt. Oxford: Oxford University Press. LKN2030 (2012a) Leuven Klimaatneutraal 2030. Presentatie persconferentie 29 februari 2012. Leuven.

LKN2030 (2012b) Leuven Klimaatneutraal. Resultaten van de nulmeting. Leuven. LKN2030 (2016) Missie Zero Emissie. http://www.leuvenklimaatneutraal.be/missiezero-emissie (accessed 1 September 2016).

Loorbach D (2007) Transition Management. New Mode of Governance for Sustainable Development. Utrecht: International Books.

Loorbach D, Rotmans J (2006) Managing transitions for sustainable development. In: Wieczorek A J, Olsthoorn X (eds) Industrial Transformation -disciplinairy approaches towards transformation research. Dordrecht: Kluwer Academic Publishers. 
Löwy M (2001) Walter Benjamin : Avertissement d'Incendie : une Lecture des Thèses Sur le Concept d'Histoire. Paris : PUF.

MacGregor S (2014) Only Resist: Feminist Ecological Citizenship and the Post-politics of Climate Change. Hypatia 29(3): 617-633.

Machiavelli N (1998) The Prince. Chicago: University of Chicago Press.

Machin A (2013) Negotiating Climate Change. Radical Democracy and the Illusion of Consensus. New York: Zed Books.

Maeseele P (2015) Beyond the post-political Zeitgeist. In: Hansen A, Cox R (eds) The Routledge Handbook of Environment and Communication. New York: Routledge: 429-

443.

Mair P (2006) Ruling the Void? The Hollowing of Western Democracy. New Left Review 42: 25-51.

Marchart O (2007) Post-Foundational Political Thought: Political Difference in Nancy, Lefort, Badiou and Laclau. Edinburg: Edinburgh University Press.

Mason K, Whitehead M (2012) Transition Urbanism and the Contested Politics of Ethical Place Making. Antipode 44(2): 493-516.

McCarthy J (2013) We Have Never been "Postpolitical". Capitalism Nature Socialism 24(1): 19-25.

Moore J (2015) Capitalism in the Web of Life. Ecology and the Accumulation of Capital. London: Verso.

Mouffe C (1993) The Return of the Political. London: Verso.

Mouffe C (2000) The Democratic Paradox. London: Verso.

Mouffe C (2002) Politics and passions. The stakes of democracy. London: CSD

Perspectives.

Mouffe C (2006) On the Political. London: Routledge.

Mouffe C (2013) Agonistics. Thinking the World Politically. London: Verso.

Mueller T, Bullard N (2011) Beyond the 'Green Economy': System Change, Not Climate

Change? Global Movements for Climate Justice in a Fracturing World. Geneva: UNRISD Conference.

Mueller T, Passadakis A (2010) Another Capitalism is Possible? From World Economic Crisis to Green Capitalism. In: Abramsky K (ed) Sparking a Worldwide Energy Revolution. Social Struggles in the Transition to a Post-Petrol World. Oakland: AK Press, Oakland: 554-563. 
Neal S (2013) Transition culture: Politics, localities and ruralities. Journal of Rural Studies 32: 60-69.

North P (2010) Eco-Localisation as a progressive response to peak oil and climate change. A sympathetic critique. Geoforum 41(4): 585-594.

Offe C (2009) Governance: An “Empty Signifier"? Constellations 16(4): 550-562.

Parekh B (1982) Marx's Theory of Ideology. Baltimore: The John Hopkins University Press.

Pepermans Y, Maeseele P (2014) Democratic Debate and Mediated Discourses on Climate Change: From Consensus to De/politicization. Environmental Communication: A Journal of Nature and Culture 8: 216-232.

Rancière J (1999) Disagreement : Politics and Philosophy. Minneapolis: University of Minnesota Press.

Rancière J (2001) Ten Theses on Politics. Theory \& Event 5(3).

Rancière J (2005) Chroniques des Temps Consensuels. Paris : Seuil.

Rotmans J (2003) Transitiemanagement: sleutel voor een duurzame samenleving. Assen: Van Gorcum.

Rotmans J, Loorbach D (2009) Complexity and Transition Management. Journal of Industrial Ecology 13: 184-196

Schmitt C (1988) Political Theology. Four Chapters on the Concept of Sovereignty. Cambridge: MIT Press.

Swyngedouw E (2005) Governance Innovation and the Citizen: The Janus Face of Governance-beyond-the-State. Urban Studies 42(11): 1991-2006.

Swyngedouw E (2007) Impossible 'Sustainability' and the Postpolitical Condition. In: Krueger R J, Gibbs D (eds) The Sustainable Development Paradox. London: The Guilford Press: 185-205.

Swyngedouw E (2009) The Antinomies of the Postpolitical City: In Search of a Democratic Politics of Environmental Production. International Journal of Urban and Regional Research 33: 601-620.

Swyngedouw E (2010) Apocalypse Forever? Theory, Culture \& Society 27: 213-232. Swyngedouw E (2013) The Non-political Politics of Climate Change. ACME: An International E-Journal of Critical Geographies 12(1): 1-8.

Swyngedouw E, Kaika M (2014) Urban Political Ecology. Great Promises, Deadlock... and New Beginnings? Documents d'Anàlisi Geogràfica 60(3): 459-481. 
Tornaghi C (2014) Critical geography of urban agriculture. Progress in Human Geography 38(4): 551-567.

Tornaghi C, Van Dijck B (2015) Research-informed gardening activism: steering the public food and land agenda. Local Environment 20(10): 1247-1264.

UNEP (2011) Towards a Green Economy: Pathways to Sustainable Development and Poverty Eradication. www.unep.org/greeneconomy (accessed 1 September 2016). UNICE (2011) Climate Neutral Cities. How to make cities less energy and carbon intensive and more resilient to climatic challenges. New York and Geneva: United Nations.

Urry J (2011) Climate Change and Society. Cambridge: Polity Press.

Vanderheyden G, Aerts J, Achten W, Bachus K, Duflou J, Eyckmans J, Jones P T, Haers J, Motten B, Melis N, Volckaert F (2012) Nulmeting CO2 emissies KU Leuven in het jaar 2010. Kessel-Lo: KULeuven/Futureproofed.

Vandevyvere H, Jones P T, Aerts J (2013) De transitie naar Leuven Klimaatneutraal 2030. Wetenschappelijk eindrapport. Leuven.

Weymans W (2005) Freedom through Political Representation. Lefort, Gauchet and Rosanvallon on the Relationship between State and Society. European Journal of Political Theory (4): 263-282.

Žižek S (2000) The Ticklish Subject. The Absent Centre of Political Ontology. London: Verso. 